\title{
La desconfianza
}

\author{
Jordi Balló \\ Profesor Agregado (Universitat Pompeu Fabra) \\ Ivan Pintor Iranzo \\ Profesor Agregado (Universitat Pompeu Fabra)
}

\section{Referencia de este artículo}

Balló, Jordi y Pintor Iranzo, Ivan (2021). La desconfianza. En: adComunica. Revista Científica de Estrategias, Tendencias e Innovación en Comunicación, $\mathrm{n}^{\circ} 22$. Castellón de la Plana: Departamento de Ciencias de la Comunicación de la Universitat Jaume I, 377-380. DOI: http://dx.doi.org/10.6035/2174-0992.2021.22.21

En una conversación con la investigadora y curadora de arte Inge Stache desarrollada en Buenos Aires y recogida en el libro Desconfiar de las imágenes, el cineasta y teórico Harun Farocki fantaseaba con la idea de un dispositivo capaz de detectar las imágenes retocadas, manipuladas, a imagen y semejanza de la tecnología de descodificación del ADN (Farocki, 2015: 290). Las imágenes, como billetes auténticos o falsos, revelarían así su auténtica naturaleza ante un aparato cuya evocación permitía a Farocki insistir en la necesidad de restablecer el pacto con un narrador visual fiable, en la exigencia de una reactivación del contrato entre autor y espectador. Vivimos tiempos en los que el análisis de las imágenes que se crean en la esfera pública debe partir de una aproximación al principio de la autopuesta en escena y que, por lo tanto, debe constatar que la imagen aparece mediatizada o, como señala Carlos Alberto Scolari, «hipermediada» (Scolari, 2008) por inscribirse en un sistema de control y autorepresentación complejo. Ante la imagen, ante el constante flujo de imágenes, no queda hoy otra actitud que la distancia crítica y la elucidación y transmisión de mecanismos capaces de sugerir alternativas desde la alfabetización mediática. 
Desde el punto de vista de la iconografía, además, podría parecer que las redes sociales no han hecho sino acelerar y multiplicar la onda expansiva de una ley tan arcaica como la existencia humana: escribe la historia y vencerás. La economía de la atención que sustenta el consumo de información a través de la red constituye tanto una lucha por la apropiación de los discursos como un mero ejercicio de reclamo, una búsqueda de la adhesión espontánea y el like. Si se acepta que las imágenes que encarnan el poder y los diferentes avatares de la vida pública en los medios de comunicación se articulan a través de motivos visuales procedentes del cine, la pintura o incluso el legado de la literatura y el acervo oral, la capacidad de esos motivos para vehicular contenido emocional a través de su persistencia dinámica los convierte en un nodo fundamental de la circulación de información a través de las redes. Los patrones de reconocimiento socialmente compartidos en motivos como la investidura presidencial, la salida a bolsa o la retórica de las colas de gente que muestra la crisis de un país son formas visuales que atraviesan, con la estela de una memoria no siempre evidenciada, todas las formas comunicativas.

Son imágenes pensadas, que suelen recurrir a gestos y motivos anclados en el imaginario del espectador, apelaciones a las trazas de una memoria visual compartida que, en manos de teóricos de la cultura y la imagen como el padre de la iconología, Aby Warburg o su principal difusor, el historiador del arte Georges Didi-Huberman, han dado en llamarse supervivencias (Nachleben). De manera manifiesta, la fuerza de la ambigüedad de la imagen está ahí para mantener viva su autonomía, su capacidad de ser recreada e incorporarse a la eterna cadena de creación de significados. La reapropiación consciente de este tipo de imágenes funciona como un contraplano, que construye una actitud crítica, que hace dialogar la imagen con su reverso e introduce un espacio de reflexión, una grieta, un intervalo. Esta condición de asentamiento, de detención, provoca que, a pesar de lo que pudiera parecer, no siempre sea la imagen la herramienta más eficiente para crear los bulos y las noticias falsas, que con enorme frecuencia aparecen vinculadas a otro tipo de estrategias, textuales o fundadas precisamente en la ausencia de formas visuales.

Si, como el filósofo esloveno Slavoj Žižek señala en Viviendo en el final de los tiempos en una paráfrasis de Baudrillard, ya no existe un mundo real y un mundo de las imágenes, sino que las imágenes constituyen la realidad (Žižek, 2012). ¿Cómo afrontamos el análisis de estas imágenes? Ahora más que nunca la distancia crítica es necesaria, así como transmitir el reconocimiento de los mecanismos de ocultación. Cuando las imágenes generadas desde el poder obtienen su mayor eficiencia es cuando logran borrar las huellas de su construcción visual, cuando parecen fruto de una normalidad que el espectador no es capaz de cuestionar porque parece indiscutible. Eso se produce cuando el resultado que se transmite elimina la memoria del ensayo previo, de los protocolos prestablecidos. Por eso es tan importante compartir las formas de análisis con los procedimientos que pueden sugerir el estudio de trabajo de las imágenes, los production studies (Mayer, 
Banks y Caldwell, 2009): recurrir a las fuentes originales de la producción de esas imágenes o de las decisiones sobre su circulación para poder comprender mejor los protocolos que las generan. El modo en que los diversos cuerpos policiales mundiales presentan el resultado de un decomiso en forma de bodegón o las características de la retransmisión en directo un acto político o religioso cargado de significado visual constituyen casos evidentes de esta capacidad de invisibilización de un proceso creativo cargado de significación ideológica.

Es precisamente este predominio de lo oculto lo que exige de manera más acuciante explorar las imágenes, las secuencias, el registro de lo visual. La falsedad de una imagen no concierne únicamente a su manipulación grosera y directa, sino también al mecanismo más sutil de su propia condición de imagen controlada. El ejercicio de aprender a desplazar la mirada a los detalles imprevistos, a los contornos de la imagen que recomendaba Warburg — con la paráfrasis de Flaubert con la que solía abrir sus seminarios: «El buen dios está en los detalles»- constituye también una invitación a la recontextualización y al esclarecimiento del trabajo de las imágenes, de las huellas que lo evidencian. Sabemos que toda imagen contiene las claves de su propio misterio, y que su propio mecanismo de control puede quedar en evidencia si le aplicamos un principio analítico. Y en esta tarea de analizar lo falso o lo que no lo parece, es cuando emerge lo verdadero, los mecanismos que desvelan los cimientos de un sistema de representación.

\section{Referencias}

Mayer, Vicki; Banks, Miranda J. y Caldwell, John Thornton (eds.) (2009). Production Studies: Cultural Studies of Media Industries. Londres: Routledge.

Farocki, Harun (2015). Desconfiar de las imágenes. Buenos Aires: Caja Negra.

Scolari, Carlos Alberto (2008). Hipermediaciones. Elementos para una teoría de la comunicación digital interactiva. Barcelona: Gedisa.

Žižek, Slavoj (2012). Viviendo en el final de los tiempos. Madrid: Akal. 
